\title{
MODEL GUYUP REMBUG DALAM PENYELESAIAN KONFLIK : PADA KONFLIK ANTARA FORPAK DENGAN KARANG TARUNA DI DESA SIDODADI
}

\author{
Anam Miftakhul Huda,Vembita Sapna Key \\ Universitas Islam Balitar, e-mail: nandapalupi13@gmail.com
}

\begin{abstract}
ABSTRAK
Organisasi kepemudaan tumbuh dan berkembang sejalan dengan sejarah perkembangan bangsa. Sejarah perkembangan bangsa, organisasi kepemudaan merupakan salah satu wadah untuk menampung aspirasi pemuda dengan implementasinya yakni gotong royong antar pemuda untuk membantu negara, sebagai wujud kontribusi membangun dan membebaskan bangsa pada era penjajahan. Konflik merupakan sesuatu yang melekat dalam kehidupan manusia baik secara pribadi maupun antar kelompok. Konflik bukan sesuatu yang perlu ditakuti atau dihindari tetapi yang terpenting bagaimana masyarakat mampu untuk mengelola serta menyelesaikan secara benar agar konflik tersebut menjadi sesuatu yang positif bagi bersama melalui strategi yang tepat dalam penyelesaiannya. Penelitian ini ditujukan untuk melihat strategi yang digunakan oleh pemerintah desa dalam menyelesaikan konflik yang terjadi antara organisasi yang ada pada desa sidodadi. Penelitian ini dilaksanakan dengan menggunakan metode kualitatif dengan sistem wawancara terbuka pada beberapa informan yang dipilih. Penelitian ini menilai bahwa kebijakan atau sistem yang digunakan oleh pemerintah desa selaku penengah dalam konflik ini sangat tepat dengan sistem yang dikenal dengan nama Guyup Rembug selain karena efisiensinya, sistem ini juga merupakan sistem penyelesaian konflik yang dapat digunakan untuk mengambil keputusan secara adil dan bijaksana oleh pengambil keputusan pada sistem Guyup Rembug ini.
\end{abstract}

Kata kunci : Strategi, Konflik, Guyub Rembug 


\section{ABSTRACT}

Youth organizations grow and develop in line with the nation's developmental history. In the history of the nation's development, youth organization is one of the containers to accommodate youth aspirations with the implementation of mutual cooperation among the youth to help the state, as a form of contribution to build and liberate the nation in the era of colonialism. Conflict is something inherent in human life both personally and inter-group. Conflict is not something that needs to be feared or avoided but most importantly how people are able to manage and resolve it right in order for the conflict to be a positive thing for the people through the right strategy in their solution. This study is aimed at looking at the strategies used by village governments in resolving conflicts between existing organizations in the village of Sidodadi. This research was conducted by using qualitative method with open interview system on selected informants. This study assesses that the policy or system used by the village government as mediator in this conflict is very precise with a system known as Guyup Rembug in addition to its efficiency, it is also a conflict resolution system that can be used to make fair and wise decisions by decision makers on this Guyup Rembug system.

Keywords: Strategy, Conflict, Guyub Rembug

\section{PENDAHULUAN}

Lingkungan berorganisasi dalam masyarakat ini tumbuh dan berkembang dengan sangat dinamis, hal ini sangat memerlukan sistem manajemen yang efektif artinnya dapat dengan mudah berubah atau menyesuaikan diri dan dapat mengakomodasikan setiap perubahan positif, yang sedang dan telah terjadi dengan cepat, tepat, dan terarah serta tidak memakan banyak biaya. Dengan demikian, organisasi sudah tidak lagi dipandang sebagai sistem tertutup tetapi organisasi merupakan sistem terbuka yang harus dapat merespon dan mengakomodasikan berbagai perubahan internal maupun eksternal dengan cepat 
dan efisien. Konflik adalah sesuatu yang wajar dan biasa ditemui dalam bersosial di masyarakat seperti apa yang diakatakan oleh Ramlan Surbakti (1992), bahwakonflik mengandung definisi benturan, seperti perbedaan pendapat, persaingan, serta pertentangan antar individu dengan individu, individu dengan kelompok, maupun kelompok dengan kelompok, hingga pemerintah dengan individu / kelompok.

Konflik terjadi karena perbedaan dan kelangkaan kekuasaan, perbedaan dan kelangkaan posisi sosial, dalam masyarakat serta posisi sumber daya atau karena disebabkan sistem nilai dan penilain yang berbeda. Konflikpun tidak hanya terjadi pada individu saja tetapi juga dapat terjadi pada atau antar organisasi, seperti halnya yang dikatakan oleh Dahrendorf (dalam Ramlan Surbakti, 1992:40). Konflik dibedakan menjadi 4 macam :

- Konflik antara atau dalam peran sosial (intrapribadi), misalnya antara perananperanan dalam keluarga atau profesi (konflik peran (role).

- Konflik kelompok terorgarnisir dan tidak terorganisir (polisi melawan masa).

- Konflik antar satuan nasional (kampane, perang saudara)

- Konflik antar atau tidak antar agama.

- Konflik antar politik.

Begitupun dengan penelitian ini yang mengacu pada konflik antar organisasi di masyarakat yakni kasus pada konflik antara FORPAK (Forum Pemuda Klepon) yang merupakan salah satu organisasi kepemudaan di dusun klepon, yang merupakan salah satu dusun di Desa Sidodadi, dengan Karang Taruna desa sidodadi pada kegiatan pawai HUT RI di tahun 2016 ini, hari minggu, tanggal 21 Agustus 2016, tepatnya pukul satu siang bertempat di lapangan SD Katolik yakni salah satu SD di Desa Sidodadi dan merupakan tempat pemberangkatan pawai.

Konflik antar organisasi ini dikarenakan sebab - sebab khusus diantaranya kesalah pahaman, hal tersebut di dapat dari salah satu informan dari penelitian ini. Suatu konflik antar organisasi harus segera diselesaikan karena mengingat bahwa konflik akan berdampak buruk bagi kelangsungan masing - masing organisasi 
tersebut, maka dari itu dibutuhkan pihak ketiga yang netral guna sebagai fasilitator dalam penyelesaian masalah yang timbul. Akibat adanya konflik tersebut ketegangan terjadi, sehingga mewajibkan pemerintah desa untuk segera menyelesaikan konflik antar kedua organisasi ini dengan strategi yang tepat, di sinilah ditetapkan strategi Guyub Rembug yang merupakan strategi penyelesaian konflik oleh Desa Sidodadi.

Penelitian ini ditujukan untuk mengetahui bentuk strategi penyelesaian konflik pada Desa Sidodadi dengan strategi yang bernama Guyup Rembug, selain itu ditujukan juga untuk agar mengetahui proses konflik yang nyata terjadi pada masyarakat di desa, serta sebab - sebab yang umum menjadi faktor awal terjadinya konflik, dan proses terjadinya konflik antara kedua organisasi ini di Desa Sidodadi.

Diharapkan pula dengan adanya penelitian ini bisa memberi informasi tentang teori - teori yang berhubungan dengan konflik organisasi serta juga memberi informasi tentang strategi penyelesaian konflik Guyub Rembug sebagai wujud dari bentuk strategi penyelesaian konflik yang lain di suatu desa yang tepatnya di Desa Sidodadi.

\section{TINJAUAN PUSTAKA}

\section{Konflik}

Konflik berasal dari kata kerja latin configure yang berarti saling memukul. Secara sosiologi, konflik diartikan sebagai sebagai suatu proses sosial antara dua orang atau lebih (bisa juga kelompok) dimana salah satu pihak berusaha menyingkirkan pihak lain dengan menghancurkan atau membuatnya tidak berdaya.

Tidak bisa dipungkiri bahwa konflik mengandung definisi benturan, seperti perbedaan pendapat, persaingan, serta pertentangan antar individu dengan individu, individu dengan kelompok, maupun kelompok dengan kelompok, hingga pemerintah dengan individu / kelompok (Ramlan Surbakti, 1992).

Selain itu berikut beberapa definisi konflik: 
1. Sebagai pertentangan, pengertian Dubrin (1984:346) mengacu pada pertentangan antar individu, kelompok atau organisasi yang dapat meningkatkan keteganggan sebagai akibat yang saling menghalangi dalam pencapaian tujuan.

2. Sebagai perilaku, Tjosfold (Dalam Champoux, 1996: 295), memandang konflik dalam organisasi sebagai perilaku yang berlawanan dan bertentangan.

3. Sebagai hubungan, Martinez dan Fule (2000:274) menyatakan konflik adalah suatu hubungan yang terjadi antara dua orang, kelompok, organisasi maupun golongan.

4. Sebagai situasi, Nelson dan Quick (1997:178) melihat konflik sebagai suatu situasi dimana tujuan, sikap, emosi, dan tingkah laku, yang bertentangan menimbulkan oposisi dan sengketa antara dua kelompok atau lebih.

Berdasarkan teori diatas dapat disimpulkan bahwa konflik pada dasarnya adala sebuah proses sosial antara dua orang atau lebih, maupun antar dua kelompok atau lebih yang menuju pada sebuah persaingan yang menimbulkan pertentangan untuk menuju suatu tujuan masing - masing.

\section{Jenis - Jenis Konflik}

Menurut Dahrendorf (dalam Ramlan Surbakti, 1992:40). Konflik dibedakan menjadi 4 macam :

- Konflik antara atau dalam peran sosial (intrapribadi), misalnya antara perananperanan dalam keluarga atau profesi (konflik peran (role).

- Konflik kelompok terorgarnisir dan tidak terorganisir (polisi melawan masa).

- Konflik antar satuan nasional (kampanye, perang saudara)

- Konflik antar atau tidak antar agama.

- Konflik antar politik.

Teori diatas sampai pada kesimpulan bahwa konflik dibedakan menjadi 4 macam yakni konflik antar pribadi, konflik antar kelompok yang terstruktur dengan yang tidak terstruktur, konflik antar kelompok saudara sendiri, konflik 
antar dan tidak antar agama, dan konflik antar politiik, hal ini membuktikan bahwa konflik dapat terjadi pada siapapun dan dimanapun berada.

\section{Penyebab Konflik}

Maswadi Rauf (2001:49), mengemukakan bahwa konflik terjadi karena adanya keinginan manusia untuk menguasasi sumber-sumber posisi yang langka (resource and position scarity).

Menurut Hugh Miall dkk (2000:80-91) terdapat enam teori penyebab konflik, yakni salah satunya:

1. Teori negosiasi prinsip. Dalam teori ini menganggap bahwa konflik disebabkan oleh posisi-posisi yang tidak selaras dan perbedaan pandangan tentang konflik oleh pihak-pihak yang mengalami konflik.

Karena dalam konflik ini yang menjadi penyebabnya, relevan dengan teori dari Hugh Miall yakni teori negosiasi prinsip, dikarenakan perbedaan pandangan antar kedua organisasi yang berkonflik. Sehingga disini peneliti hanya menuliskan salah satu teorinya yang bersangkutan dengan topik hasil observasi.

Menurut Wiese dan Becker dalam Soekanto (2006:91), penyebab konflik dilatarbelakangi adanya pertentangan dan perbedaan, sebagai berikut:

1. Perbedaan kebudayaan. Perbedaan kepribadian dari orang perorangan tergantung pula dari pola-pola kebudayaan yang menjadi latar belakang pembentukan serta perkembangan kepribadian tersebut.

2. Perbedaan antara individu-individu. Perbedaan pendirian dan perasaan mungkin akan melahirkan bentrokan antara mereka.

3. Perubahan sosial. Perubahan sosial yang berlangsung dengan cepat untuk sementara waktu dapat mengubah nilai-nilai yang ada dalam masyarakat.

4. Perbedaan kepentingan. Perbedaan kepentingan antara individu maupun kelompok merupakan sumber lain dari pertentangan.

Sebab-sebab terjadinya konflik antara lain (Diana Francis, 2006:29):

1. Struktur. Pertarungan kekuasaan antara pemilik kepentingan atau sistem yang bertentangan, persaingan untuk merebutkan sumber daya yang 
terbatas, atau saling ketergantungan dua atau lebih kelompok-kelompok kegiatan kerja untuk mencapai tujuan mereka.

2. Pribadi. Ketidaksesuaian tujuan atau nilai-nilai sosial pribadi dengan perilaku yang diperankan mereka, dan perubahan dalam nilai-nilai persepsi.

3. Komunikasi. Salah pengertian yang berkenaan dengan kalimat, bahasa yang sulit dimengerti dan informasi yang tidak lengkap.

\section{Proses Terjadinya Konflik}

Dapat diartikan jika proses terjadinya konflik sebenarnya tidaklah terjadi secara tiba - tiba, melainkan melalui suatu tahapan - tahapan tertentu. Hendricks W. (1992) mengidentifikasi proses terjadinya konflik terdiri dari tiga tahap, yaitu peristiwa sehari - hari, adanya tantangan, dan timbulnya /pertentangan.

Menurut A.M. Hardjana(1994), lingkaran konflik terdiri dari hal - hal sebagai berikut:

1. Koflik yang dirasa

2. Perilaku yang Nampak

3. Konflik ditekan atau dikelola

4. Dampak konflik

5. Kondisi yang mendahului

6. Kemungkinan konflik yang dilihat

Oleh karena itu, proses konflik itu dapat diidentifikasi guna dicari penyelesaiannya bahkan dapat pula memperbesar konflik yang ada, sesuai dari kepentingan pihak yang berkonflik. Seperti yang dimaksud oleh George F Terry (1986), konflik itu umumnya mengikuti pola yang teratur ditandai dengan timbulnya suatu krisis, selanjutnya terjadi kesalahpahaman antar individu maupun kelompok dan konfrontasi menjadi pusat perhatian, pada tahap berikutnya krisis dialihkan untuk diarahkan dan dikelola. 


\section{METODE PENELITIAN}

Menurut Sutrisno Hadi, penelitian adalah usaha untuk menemukan, mengembangkan, dan menguji kebenaran suatu pengetahuan. Usaha tersebut dilakukan dengan menggunakan metode - metode ilmiah, dengan demikian penelitian yang dilaksanakan tidak lain utnuk memperoleh data yang telah teruji kebenaran ilmiahnya. Penelitian ini menggunakan pendekatan kualitatif yang menghasilkan data secara deskriptif berupa kata - kata tertulis atau lisan dari orang - orang dan perilaku yang diamati, terdiri dari wawancara yang mendalam dan terbuka yakni data yang diperoleh terdiri dari kutipan langsung dari orang orang tentang pengalaman, pendapat, dan pengetahuan.

Pada sistem wawancara sangatlah penting dalam pemilihan narasumber atau informan yang patut dipercaya dan berpengalaman dalam pembahasan penelitian, dikarenakan penelitian ini membahas kasus konflik antara dua organisasi di desa sidodadi dan diharapkan hasil penelitian dapat seimbang maka dalam hal ini saya memilih informan yang mewakili dari kedua pihak yang berkonflik serta satu pihak dari perangkat desa yang merupakan wakil dari saksi penyelesaian dari konflik kedua organisasi tersebut dengan strategi Guyub Rembug. Yakni yang pertama Bapak Siswoyo adalah anggota senior dari FORPAK (Forum Pemuda Klepon), yang merupakan salah satu organisasi yang ada di dusun klepon, dan Bapak Hari yang merupakan anggota dari Karang Taruna Desa Sidodadi, serta Bapak Jaka yang merupakan Pamong dari Desa Sidodadi sekaligus membantu Kepala Desa dalam penyelesaian konflik.

Selain itu seperti yang dikatakan di atas, pada penelitian ini menggunakan analisis dengan pendekatan kualitatif, oleh karena itu data yang telah dikumpulkan dan telah di cek keabsahannya serta dinyatakan valid, dapat diproses melalui langkah - langkah yang bersifat umum, yakni:

a. Reduksi data yakni data yang diperoleh di lapangan ditulis dalam bentuk uraian atau laporan yang terperinci. Laporan tersebut direduksi, dirangkum, dipilih hal -hal yang pokok, difokuskan pada hal -hal yang penting, dicari tema dan polanya. 
b. Mengambil kesimpulan dan verifikasi, yakni data yang telah terkumpul telah direduksi, lalu dicari maknanya kemudian dilakukan penarikan kesimpulan akhir.

\section{PEMBAHASAN DAN HASIL PENELITIAN}

Organisasi kepemudaan yakni perkumpulan sosial yang dibentuk oleh para pemuda ataupun masyarakat yang berbadankan hukum ataupun tidak berbadan hukum, dengan sukarela atas dasar kesamaan kegiatan, tujuan yang berfungsi sebagai sarana partisipasi pemuda dalam pembangunan bangsa dan Negara. Karena di dalam masyarakat berdiri banyak organisasi kepemudaan yang memiliki visi dan misi masing - masing maka hal ini memaksa untuk antar organisasi saling berhubungan satu sama lain dan pada proses berhubungan tersebut tidak dipungkiri akan mengalami sedikit benturan, perbedan, pertentangan atau konflik atar keduanya. Sebagai pertentangan, pengertian Dubrin (1984:346) mengacu pada pertentangan antar individu, kelompok atau organisasi yang dapat meningkatkan keteganggan sebagai akibat yang saling menghalangi dalam pencapaian tujuan.

Seperti halnya pada hasil penelitian yang saya lakukan pada Desa Sidodadi. Desa Sidodadi adalah desa di kecamatan garum yang terdiri dari tiga dusun yakni dusun sidodadi, dusun kemloko dan dusun klepon. Di desa sidodadi berdiri beberapa organisasi kepemudaan antara lain Karang Taruna desa sidodadi dan FORPAK (forum pemuda klepon) yang pada pembahasan ini kedua organisasi kepemudaan tersebut mengalami konflik di tahun 2016 ini. Tidak bisa dipungkiri bahwa konflik mengandung definisi benturan, seperti perbedaan pendapat, persaingan, serta pertentangan antar individu dengan individu, individu dengan kelompok, maupun kelompok dengan kelompok, hingga pemerintah dengan individu / kelompok (Ramlan Surbakti, 1992).

Banyak organisasi, institusi dan lembaga yang besar yang memiliki banyak anggota maupun partisipan di dalamnya yang mengalami konflik seperti ini. dalam masyarakat lebih sering lagi, contohnya konflik antar kampung, jalan dan banyak lagi. Seperti halnya konflik ini juga terjadi pada salah satu kegiatan 
desa yakni pawai bulan kemerdekaan yang merupakan program kerja dari Karang Taruna Desa Sidodadi. Bapak Hari salah satu informan yang mewakili dari Karang Taruna Desa Sidodadi memaparkan bahwa:

Konflik itu gini mbk, terjadi pada acara agustusan yang diselenggarakan oleh pemerintah Desa Sidodadi, dan sing menjadi panitia adalah Karang Taruna Desa, harinya minggu mbk, tanggal 21, jam satu di tempat start pawai nang SDK kuwi mbk.

Beliau menyatakan bahwa konflik tersebut terjadi pada tgl 21 pukul satu siang bertempat di halaman SD Katolik di Desa Sidodadi yang merupakan tempat awal pemberangkatan pawai.

Selanjutnya awal mula terjadinya konflik kedua kelompok ini adalah karena pihak Karanr Taruna mengikut sertakan Dusun Klepon untuk bergabung pada acara tersebut, dan sebelumnya Dusun Klepon melalui FORPAK sudah mempunyai kegiatan serupa tetapi hanya sebatas dusun yang sekaligus menjadi agenda tahunan dari Dusun Klepon dengan FORPAK menjadi panitianya. Seperti yang dipaparkan oleh Bapak Siswoyo selaku informan yang mewakili dari pihak FORPAK menceritakan awal konflik yakni:

Awalnya terjadinya konflik seperti ini dek, saat itu acara pawai HUT RI, saat itu saya menjadi panitia di dusun klepon karena waktu itu dusun klepon sebenarnya akan melaksanakan sendiri kegiatan pawainya, hanya sebatas dusun klepon saja, dan kepanitiannya diambil dari forpak, tapi pada saat $H-1$ pelaksanaan pawai dusun, perwakilan dari pihak karang taruna desa sidodadi datang untuk meminta agar dusun klepon ikut bergabung menjadi peserta di pawai desa yang juga diadakan pada hari yang sama.

Dalam hal waktu pemberitahuan ini merupakan salah satu penyebab konflik mengenai komunikasi, dari pihak panitia juga mengakui tentang keterlambatan waktu pemberitahuan kegiatan tersebut dan menjelaskan alasannya, yang dipaparkan oleh Bapak Hari selaku panitia dan anggota Karang Taruna, jelasnya: 
Masalah waktu lek ngomongi sing jarene ndadak itu gini mbak sebenarnya, soalnya rencana berubah tiga hari sebelum pawai, padahal rencana sebelume itu peserta pawai hanya perwakilan $R T$ dari masing masing dusun, karena ingin ben rame mbk, ben mundak meriah, panitia punya usulan pingin mengajak seluruh RT Desa Sidodadi, akhire lek omongi per dusun yo ndadak mbk, lek masalah Forpak ape ngenekne pawai waktune pas bareng itu panitia jan gak sengojo ngerti mbk.

Dari penjelasan Bapak Hari didapatkan bahwa rencana yang berubah secara mendadak membuat waktu pemberitahuan pada peserta pawai terutama Dusun Klepon juga mendadak, dan untuk masalah samanya waktu pelaksanaan rencana pawai Dusun Klepon itu merupakan ketidak tahuan dari pihak panitia yang merupakan Karang Taruna Desa Sidodadi.

Hal ini membuktikan bahwa penyebab konflik kedua organisasi ini salah satunya yaitu lemahnya komunikasi antara pihak Karang Taruna Desa Sidodadi dengan FORPAK ( Forum Pemuda Klepon), dan akhirnya dengan berbagai pertimbangan dusun klepon bersedia untuk bergabung, tetapi setelah hari pelaksanaan tak disangka awal dari konflik tersebut terjadi yakni seperti yang dikatakan oleh Bapak Siswoyo:

Konflik itu terjadi pada awalnya di start pemberangkatan peserta pawai yang memang tidak disediakan nomor urut, akhirnya mulai berebut untuk duluan berjalan, disana sudah mulai perang kata - kata kasar dan dorong - dorongan, apalagi tambah dengan beberapa masyarakat klepon di berhentikan oleh polsek yang berjaga, katanya tidak boleh melanjutkan karena dianggap mengganggu ketertiban, dari situlah forpak maju dan protes untuk membela masyarakat klepon yang mengikuti pawai, tapi ya namanya anak muda itu tidak bisa menahan emosi.

Pada intinya berdasarkan penjelasan dari Bapak Siswoyo dan Bapak Hari, alur terjadinya konflik tersebut yakni diawali dengan mendadaknya pemberitahuan atau undangan ikut serta dalam pawai serta berebut posisi urutan untuk berjalan dikarenakan pihak panitia (Karang Taruna) tidak menyediakan no 
urut, akhirnya semua peserta ingin terdepan untuk pawai tersebut, tak ketinggalan juga pihak Dusun Klepon yang di cover oleh FORPAK.

Hal ini menunjukan bahwa konflik antar kelompok terjadi yakni antara FORPAK dengan Karang Taruna yang di awali dengan sebuah krisis komunikasi yang menimbulkan kesalah pahaman antar organisasi ini selain itu ketersinggungan perasaan juga menjadi dasar adanya konflik ini. Ini juga didukung dengan adanya pendapat dari Diana Francis (2006:26)Sebab-sebab terjadinya konflik antara lain:

1. Komunikasi :Salah pengertian yang berkenaan dengan kalimat, bahasa yang sulitdimengerti dan informasi yang tidak lengkap.

2. Struktur :Pertarungan kekuasaan antara pemilik kepentingan atau sistem yang bertentangan, persaingan untuk merebutkan sumber daya yang terbatas, atau saling ketergantungan dua atau lebih kelompok-kelompok kegiatan kerja untuk mencapai tujuan mereka.

3. Pribadi :Ketidaksesuaian tujuan atau nilai-nilai sosial pribadi dengan perilaku yang diperankan mereka, dan perubahan dalam nilai-nilai persepsi.

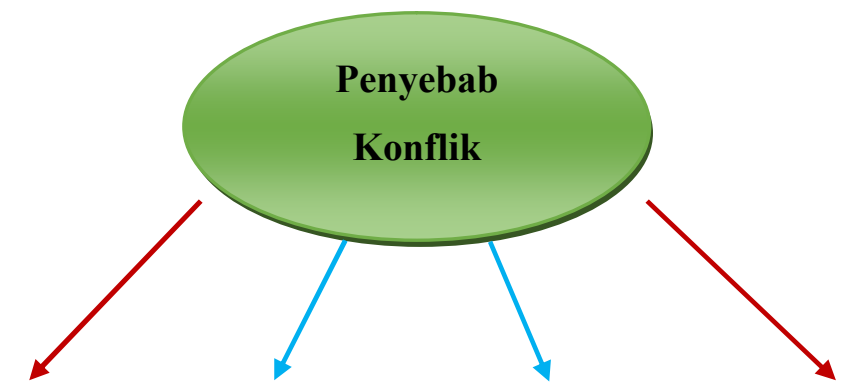

\section{Perasaan}

Salah Faham Konflik Pribadi Provokator Ketersinggungan

Gambar 1. Model Gejala Konflik FORPAK dengan Karang Taruna

Sumber : Peneliti 2016 
Penjelasanpun juga ditambah oleh Bapak Jaka selaku pamong Desa Sidodadi yang sekaligus merupakan informan ketiga dari penelitian ini, sedikit memaparkan secara ringkas bahwa:

Sebenarnya konflik itu menurut saya terjadi karena kesalah pahaman saja karena tingkat komunikasi itu tadi lo, yang memang kurang dari pihak panitia, kemepetan waktu pemberitahuan itu juga bisa, jadi menurut saya pihak klepon atau FORPAK kecewa, karena ketersediaanya malah menghasilkan sesuatu yang kurang memuaskan sehingga diluapkan dengan kekesalan yang akhirnya jadi konflik itu.

Proses dari konflik seharusnya dapat diidentifikasi untuk dicari penyelesaiannya atau malah bisa memperbesar konflik yang ada, itulah yang dimaksud oleh George F Terry (1986) yang menyatakan bahwa konflik itu pada umumnya mengikuti pola yang teratur yang ditandai dengan timbulnya suatu krisis, selanjutnya terjadi kesalahpahaman antar individu maupun kelompok dan konfrontasi menjadi pusat perhatian, pada tahap berikutnya krisis dialihkan untuk diarahkan dan dikelola.

\section{Strategi Penyelesaian Konflik Guyup Rembug}

Dalam menyelesaikan konflik ini pemerintah desa sidodadi menempatkan dirinya sebagai pihak ketiga yang netral, dengan menggunakan strategi Guyup Rembug. Guyup rembug berasaldari bahasa jawa yakni Guyup artinya bersama/ bersatu dan Rembug artinya musyawarah, jadi guyup rembug adalah musyawarah bersama yang dilakukan antara pihak yang berkonflik dengan disertai pihak ketiga, dalam pelaksanaanya guyup rembug memiliki satu prinsip yang menjadi dasar apabila dilaksanakannya strategi ini, seperti apa yang dikatakan Bapak Siswoyo yakni:

Pokoknya dek, guyup rembug itu tidak hanya sekedar musyawarah mufakat biasa tetapi disini ada prinsip dasarnya yakni rebutan salah.

Rebutan salah juga berasal dari bahasa jawa yakni berebut kesalahan yang dilakukan oleh kedua kelompok yang berkonflik, karena diharapkan dengan prinsip itu data - data untuk bahan pengambilan keputusan dapat banyak 
pertimbangan, karena dari berbagai sudut pandang yang nantinya dikumpulkan dan diolah menjadi satu.

Pada hal ini Bapak Jaka juga menambahkan penjelasan tentang Guyub Rembug yang saat itu beliau juga membantu Kepala Desa untuk menyelesaikan konflik antar organisasi ini, paparnya:

Guyup rembug ini sebenarnya cuma bahasa saja, yo wes sing intinya proses menyelesaikan konflik dengan langkah - langkah: sing pertama mendalami masalah, trus kedua ngomong - ngomong dulu, ketiga nego sek, keempat baru musyawarah, trus terakhir pengambilan keputusan oleh pak lurah, dan yang penting disini saat musyawarah diterapkan system rebutan salah dek, jadi kedua pihak yo kudu mengoreksi sendiri-sendiri salahnya trus di utarakan, begitu.

Sistem kerja dari guyup rembug ini adalah yang pertama ditelusuri dan dipelajari pokok penyebab konflik, lanjut dilakukan pembicaraan tertutup dengan masing - masing organisasi yang berkonflik secara terpisah, guna menambah data, setelahnya barulah dipertemukan perwakilan masing - masing organisasi yang paling dipercaya untuk hadir dalam guyup rembug, dan disana nanti akan ada penengah langsung oleh kepala desa yang juga pengambil kebijakan, dan disaat itu prinsip rebutan salah diimplementasikan, karena peraturannya siapa yang tidak mengatakan kesalahannya itu dianggap yang bersalah, sehingga pasti berjalan proses kerja guyup rembug ini. Dan terakhir dengan berbagai pertimbangan kepala desa mengambil kebijakan yang seadil -adilnya untuk kedua belah pihak, dan mendamaikannya.

Pada kasus ini akhirnya dengan berbagai pertimbangan kepala desa mengambil kebijakan untuk mentiadakan sementara pawai dengan waktu yang telah ditentukan yakni 2 tahun. Karena setelah diketahui bahwa penyebab konflik antar organisasi ini hanya karena salah paham dan kurangnya komunikasi serta proses melebih - lebihkan untuk dimanfaatkan oleh oknum tertentu guna kepentingannya dan keuntungannya sendiri. 


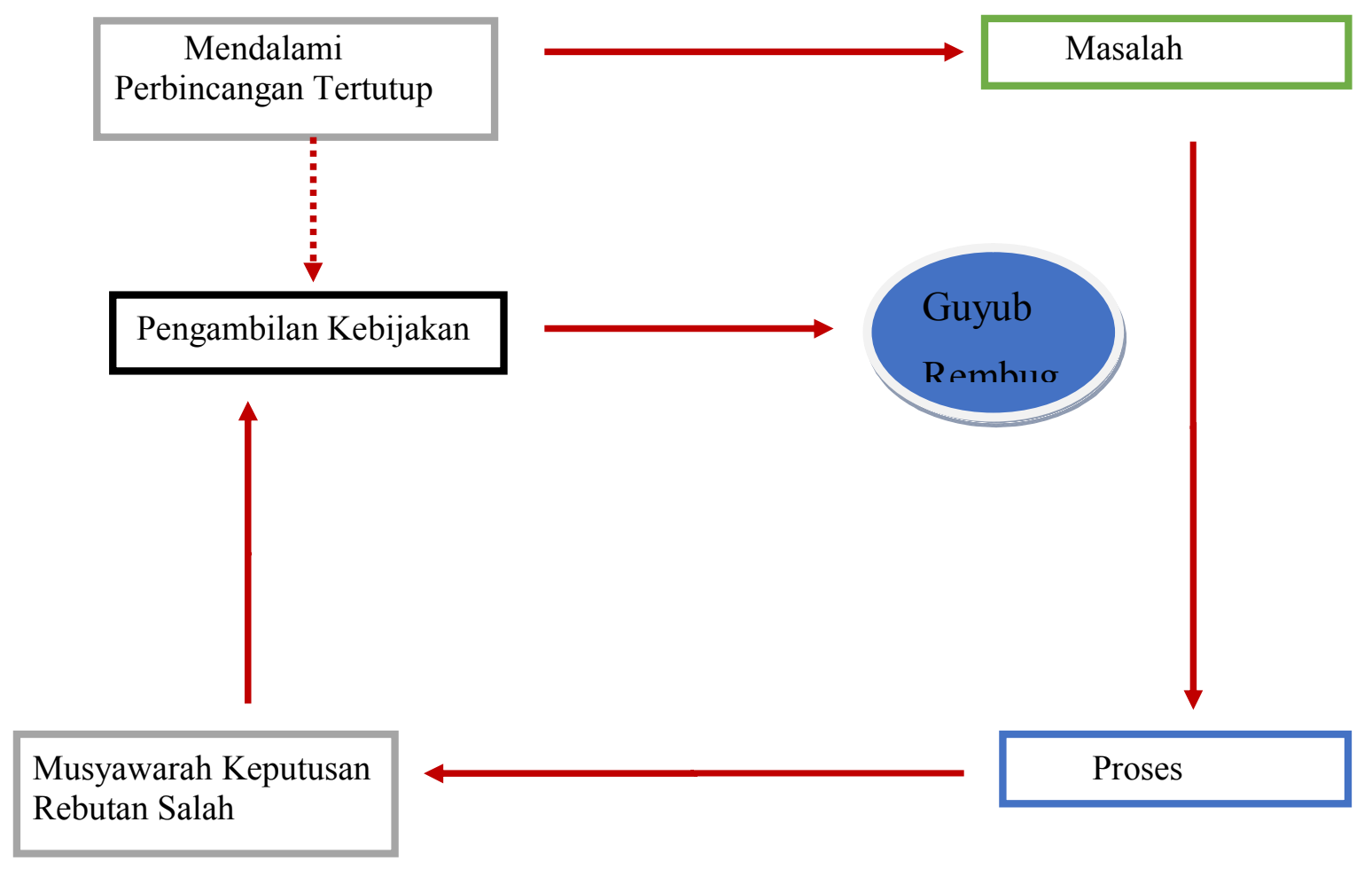

Gambar 2. Model Penyelesaian Konflik Guyub Rembug Sumber: Peneliti 2016

\section{PENUTUP}

Dari pembahasan diatas dapat ditarik kesimpulan bahwa konflik antar organisasi kepemudaan di desa sidodadi yang terjadi pada tahun 2016 ini, diantaranya terjadi dikarenakanakan faktor kurang komunikasi sehingga menimbulkan salah paham, namun terdapat juga faktor lainnya yang sifatnya sepele seperti persinggungan perasaan dan masalah priadi antar individu. Kondisi demikian dapat menyebabkan tidak harmonisnya hubungan yang ada di tengah warga. Strategi penyelesaian konflik dengan sistem Guyup Rembug dengan prinsip rebutan salah menjadi acuan untuk menyelesaikan konflik di lingkup desa sidodadi, karena strategi Guyup Rembug menggambarkan strategi penyelesaian 
konflik yang baik, karena prinsipnya yang unik. Dalam hal ini Guyup Rembug sangat membantu sebagai solusi di desa sidodadi dalam menyelesaikan konflik antar kelompok, karena selain itu Guyup Rembug juga mementingkan transparansi, dan kenetralan yang dapat dipertanggung jawabkan nantinya.

\section{DAFTAR PUSTAKA}

Abdul Wahab Solichin. 2009. Analisis Kebijaksanaan.Bumi Aksara.Jakarta.

Arikunto Suharsimi. 1998. Prosedur Penelitian.Rineka Cipta. Bandung.

Arni Muhammad. 2005. Komunikasi Organisasi.Bumi Aksara. Jakarta.

Berlo, David K, 1960. The process of communication, New York : Holt, Rinehart \& Winston

Francis,Diana. 2006. Teori Dasar Tranformasi Konflik Sosial. Alih bahasa Hindrik

Koentjaningrat, 1983. Metode penelitian masyarakat, Jakarta : Gramedia

Luthans, Fred, 2006. Perilaku organisasi, Yogyakarta : Andi

Miall, Hugh. Oliver Ramsbotham dan Tom Woodhouse. 2000. Resolusi Damai Konflik Kontemporer. Jakarta: Raja Grafindo Persada.

Moleong, Lexy J, 2001. Metode penelitian kualitatif, Bandung : PT Remaja RosdakaryaMuntu, Yossi Suparyo. Yogyakarta: Quills.

Nazir, Mohamad. 1988. Metode penelitian, edisi ketiga, Jakarta : Ghalia Indonesia

Nimran, Umar, 2004. Perilaku organisasi, Surabaya : CV Citra Media

Rauf, Maswadi. 2001. Konsensus dan Konflik Politik: Sebuah Penjajagan Teoritis, Jakarta: Direktorat Jenderal Pendidikan Tinggi Departemen Pendidikan Nasional.

Soekanto, Soerjono. 2006. Sosiologi Suatu Pengantar.Jakarta: Raja Grafindo Persada

Stephen P. Robbins. 1999. Prinsip -prinsip perilaku organisasi, edisi kelima, Erlangga. Jakarta

Surbakti, Ramlan, 1992, Memahami Ilmu Politik, Gramedia Widya Sarana,Jakarta.

Sutarto.2008. Dasar-Dasar Organisasi. Gajahmada University Press. Yogyakarta 